\title{
Phytochemical screening and in vitro evaluation of free radical scavenging activity of Cordia macleodii bark. (HOOK.F. \& THOMSON)
}

\author{
Pankaj B. Nariya, ${ }^{* 1}$ V. J. Shukla, ${ }^{2}$ R. N. Acharya ${ }^{3}$ \\ ${ }^{* 1}$ Research Scholar in Phyto Chemistry \\ ${ }^{2}$ Head of the Department Pharmaceutical Laboratory, Department of Pharmaceutical Laboratory \\ ${ }^{3}$ Reader Dravyaguna Department, IPGT \& RA-G.A.U., Jamnagar
}

Submission Date: 20-4-2012; Accepted Date: 6-8-2012

\begin{abstract}
Antioxidant activity has been assessed by in vitro method for phytochemical fraction of plant, viz. methanolic and butanol extracts of Cordia macleodii bark. This investigation was under taken to evaluate methanolic and butanol extract of Cordia macleodii bark for possible antioxidants potential. The extracts were evaluated for their phenolic content $\&$ antioxidant activity. Phenolic content was measured using Folin-ciocalte reagent \& was calculated as Gallic acid equivalents. Antiradical activity of both extracts was measured by 1,1 , diphenyl-2, picrylhydrazyl (DPPH) assay \& was compared to ascorbic acid and Ferric reducing power (FRAP) of the extract was also evaluated by Oyaizu et al. In the present study three in vitro models were used for evaluate of antioxidant activity. The first two methods were for direct measurement of radical scavenging activity \& remaining one method evaluated the reducing power. The present study revealed the Cordia macleodii bark has significant radical scavenging activity.
\end{abstract}

Keywords: antioxidant, reducing power, anti-radical, DPPH, in vitro, Cordia macleodii.

\section{INTRODUCTION}

Since ancient times, the medicinal properties of plants have been investigated in the recent scientific developments throughout the world, due to their potent antioxidant activities. As antioxidants have been reported to prevent oxidative damage caused by free radical, it can interfere with the oxidation process by reacting with free radicals, chelating, catalytic metals and also by acting as oxygen scavengers. ${ }^{[1,2]}$ Reactive oxygen species (ROS) including free radicals such as superoxide anion radicals $\left(\mathrm{O}_{2}\right)$, hydroxyl radicals $\left(\mathrm{OH}_{-}\right)$non-free radicals such as $\mathrm{H}_{2} \mathrm{O}_{2}$, Singlet Oxygen $\left(\mathrm{O}_{2}\right)$ along with various forms of active oxygen are involved in various physicochemical processes in the body and aging ${ }^{[3]}$ derivatives of oxygen, attributed as reactive oxygen species

*Corresponding address:

Cell: 919898081779

Email: pankajnariya@yahoo.co.in

DOI: $10.5530 / a x .2012 .3 .5$
(ROS), are continuously generated inside the human body. The generated ROS are detoxified by the antioxidants present in the body. However, overproduction of ROS and/or inadequate antioxidant defence can easily affect and persuade oxidative damage to various bimolecular including proteins, lipids, lipoproteins and DNA. ${ }^{[4]}$ This oxidative damage is a critical etiological factor implicated in several chronic human diseases such as diabetes mellitus, cancer, atherosclerosis, arthritis and neurodegenerative diseases and also in the ageing process. Moreover, knowledge and application of such potential antioxidant activities in reducing oxidative stresses in vivo has prompted many investigators to search for potent and cost-effective antioxidants from various plant sources. ${ }^{[5-8]}$ Antioxidants are micronutrients that have gained importance in recent years due to their ability to neutralize free radicals or their actions. ${ }^{[0]}$ The majority of the antioxidant activity is due to the flavones, isoflavones, flavonoids, anthocyanin, coumarin lignans, catechins and isocatechins. ${ }^{[10]}$ These research activities have contributed to new or renewed public interests worldwide in Phyto- medicines. 
Pankaj B. Nariya, et al.: Phytochemical screening and in vitro evaluation of free radical scavenging activity

Cordia macleodii (Boraginaceous) commonly known as Dahiphal (Hindi). Cordia macleodii (Boraginaceae), native to India, has been traditionally reported to be used as aphrodisiac, for mouth sores and especially for jaundice. ${ }^{[1]]}$ The bark of the C. macleodii have been reported to have antibacterial and antifungal activity. ${ }^{[12]}$ This plant has been also highlighted for different enthnopharmacological properties. ${ }^{[13]}$ Phytoconstitute of stem barks of $C$. macleodii is not yet known. No other scientific data was found for the bark samples of the plant. Preliminary phytochemical analysis of C. macleodii bark indicated the presence of relatively high levels of flavonoids, alkaloids, steroids and terpenoids. Several flavonoids are reported to possess antioxidant and hepatoprotective properties, ${ }^{[14]}$ hence the present investigation was undertaken to determine the antioxidant potential of C. macleodii bark.

\section{MATERIALS AND METHODS}

\section{Plant materials}

Fresh bark of Cordia macleodii was collected in Orissa, India in March-April 2009 and was authenticated by Pharmacognosy Department of Gujarat Ayu UniversityJamnagar, India.

\section{Preparation of extracts}

The bark was shade dried and crushed to make coarse powder. The powder was extracted with of methanol $(95 \% \mathrm{v} / \mathrm{v})$ by continuous extraction method for $48 \mathrm{~h}$. Solvent was distilled off and the extract was concentrated and dried under reduced pressure, which yielded a brownish green mass. The extract was preserved at 2-4 C. Take $5 \mathrm{gm}$ of dried $\mathrm{MeOH}$ extract and partition with $80 \mathrm{ml}$ butanol (saturated) then butanol layer was evaporated. This crude extract of methanol and butanol was used for further investigation for potential antioxidant properties. This crude extract was used for further investigation for potential antioxidant properties.

\section{CHEMICALS}

2,2-Diphenyl-1-Picryl Hydrazyl (DPPH, Lancaster-UK), Methanol GR (99.8\%) (Loba-India), Gallic Acid (Loba-India), were purchased from Krishna Scientific Traders, Rajkot (Gujarat), India. Folin Ciocalteu's reagent and sodium carbonate solution was obtained from the pharmaceutical chemistry laboratory of IPGT \& RA, Gujarat Ayurveda University in Jamnagar.

\section{Preliminary phytochemicals screening of extract}

The methanolic extract was testing to detect for the presence of different chemical groups of compounds as per the methods described in API. Preliminary phytochemicals screening shows the presences of relatively high levels of flavonoid, alkaloids, steroids terpenoids, tannin, coumarines, etc. Isolation and Identification of marker compound from bark and further investigation was under study.

\section{Antioxidant assay}

Several concentrations ranging from $10-250 \mu \mathrm{g} / \mathrm{ml}$ of the $C$. macleodii bark were tested for antioxidant activity in different in vitro models such as, the DPPH free radical scavenging assay, phenolic content by Folin-Ciocalteau reagent and reducing power methods using Oyaizu method. All the assays were carried out in triplicate and average values were considered.

\section{FREE-RADICAL SCAVENGING ACTIVITY (DPPH ASSAY) ${ }^{[15]}$}

The free radical scavenging capacity of the methanolic and butanol extracts of C. macleodii bark was determined using DPPH method. It was measured by a decrease in absorbance at $516 \mathrm{~nm}$ of a solution of colored DPPH in methanol brought about by the sample. ${ }^{[16-18]} \mathrm{A}$ stock solution of DPPH $(1.3 \mathrm{mg} / \mathrm{ml}$ in methanol) was prepared. For sample, prepare $10 \mathrm{mg} / 10 \mathrm{ml}$ concentration of methanolic and $\mathrm{BuOH}$ extracts. From this solution $1 \mathrm{ml}$, of solution were taken in test tubes \& by dilution with same solvent up to $10 \mathrm{ml}$. This is stock solution. From stock solution $0.10,0.15,0.25,0.50,0.60 \mathrm{ml}$ was taken in different test tube. Whose concentration was then $10 \mu \mathrm{g} / \mathrm{ml}, 15 \mu \mathrm{g} / \mathrm{ml}, 25 \mu \mathrm{g} / \mathrm{ml}, 50 \mu \mathrm{g} / \mathrm{ml}, 60 \mu \mathrm{g} / \mathrm{ml}$ respectively. Freshly prepared DPPH solution $75 \mu \mathrm{l}$ $(1.3 \mathrm{mg} / \mathrm{ml})$ was added in each of these test tubes containing methanolic and butanol extracts $(5 \mu \mathrm{g} / \mathrm{ml}$, $25 \mu \mathrm{g} / \mathrm{ml}, 50 \mu \mathrm{g} / \mathrm{ml}, 75 \mu \mathrm{g} / \mathrm{ml})$ and kept in dark for $30 \mathrm{~min}$, the absorbance was taken at $517 \mathrm{~nm}$ using a Systronics UV-Visible spectrophotometer 2201). Ascorbic acid was used as a reference standard and dissolved in distilled water to make the stock solution with the same concentration of methanolic and butanol extracts. Control sample was pre-pared containing the same volume without any extract and reference ascorbic acid. 95\% 
Pankaj B. Nariya, et al.: Phytochemical screening and in vitro evaluation of free radical scavenging activity

methanol was used as blank. \% scavenging of the DPPH free radical was measured using the following equation

$\%$ inhibition $=\{($ A control - A sample $) /($ A control $)\} \times 10$

A control $=$ Absorbance of DPPH alone

A sample $=$ Absorbance of DPPH along with different concentrations of extracts.

$\mathrm{IC}_{50}$ was calculated from equation of line obtained by plotting a graph of concentration versus $\%$ inhibition.

\section{ESTIMATION OF TOTAL PHENOLIC CONTENT}

The total phenolic content of the extract was estimated according to the method described by Singleton and Rossi. ${ }^{[19]}$ Prepare $10 \mathrm{mg} / 10 \mathrm{ml}$ concentration of methanolic and $\mathrm{BuOH}$ extracts of sample. From this solution, $1 \mathrm{ml}$ of solution were taken in test tubes \& by dilution with same solvent up to $10 \mathrm{ml}$. This is stock solution. From stock solution different concentration was taken in different test tube. This same procedure used for standard. Gallic acid (Loba Chemie Pvt. Ltd., Mumbai) was used as a standard. $1 \mathrm{ml}$ of Folin-Ciocalteau reagent was added in this conc. and the content of the flask mixed thoroughly. 5 min later $4 \mathrm{ml}$ of $20 \%$ sodium carbonate was added and the mixture was allowed to stand for 30 min. with intermittent shaking. The absorbance of the blue color that developed was read at $765 \mathrm{~nm}$ in UV spectrophotometer.

\section{DETERMINATION OF REDUCING POWER}

The $\mathrm{Fe}^{3+}$-reducing power of the extract was determined by the method of Oyaizu ${ }^{[20]}$ with a slight modification. Different concentrations $(10 \mu \mathrm{g} / \mathrm{ml}, 25 \mu \mathrm{g} / \mathrm{ml}, 50 \mu \mathrm{g} / \mathrm{ml}$, $75 \mu \mathrm{g} / \mathrm{ml}, 100 \mu \mathrm{g} / \mathrm{ml}$,) of the both extracts were mixed with $2.5 \mathrm{ml}$ phosphate buffer $(0.2 \mathrm{M}, \mathrm{pH} 6.6)$ and $2.5 \mathrm{ml}$ potassium hexacyanoferrate $(1 \%)$, followed by incubation at $50^{\circ} \mathrm{C}$ in a water bath for $20 \mathrm{~min}$. After incubation, $2.5 \mathrm{ml}$ of TCA $(10 \%)$ was added to terminate the reaction and centrifuged at $3000 \mathrm{rpm}$ for $10 \mathrm{~min}$. The upper portion of the solution $(2.5 \mathrm{ml})$ was mixed with $2.5 \mathrm{ml}$ distilled water, and $0.5 \mathrm{ml} \mathrm{FeCl}_{3}$ solution $(0.1 \%)$ was added and the absorbance was measured at $700 \mathrm{~nm}$ against an appropriate blank solution. Ascorbic acid at various concentrations $(10$ to $100 \mu \mathrm{g} / \mathrm{ml}$ ) was used as standard. Increased absorbance of the reaction mixture indicated increased reducing power.

\section{RESULTS AND DISCUSSION}

\section{DPPH free radical scavenging activity}

C. macleodii exhibited a comparable antioxidant activity with that of standard ascorbic acid at varying concentration tested $(10,15,25,50,60 \mu \mathrm{g} / \mathrm{ml})$. Ascorbic acid at a concentration of $10 \mu \mathrm{g} / \mathrm{ml}$ exhibited a percentage inhibition of $52.74 \%$ and $60 \mu \mathrm{g} / \mathrm{ml}$ exhibited $99.86 \%$ (Table 1). The $\mathrm{IC}_{50}$ value of ascorbic acid was less than 10 (approx.) and is to be $6.1 \mu \mathrm{g} / \mathrm{ml}$. IC ${ }_{50}$ value was observed $22 \mu \mathrm{g} / \mathrm{ml}$ for the $\mathrm{MeOH}$ extract and $26 \mu \mathrm{g} / \mathrm{ml}$ for $\mathrm{BuOH}$ extract. (Figure 1)

\section{Total phenolic content}

Total phenolic content of $\mathrm{MeOH}$ extract and $\mathrm{BuOH}$ extract of $C$. macleodii calculated as Gallic acid equivalent of phenols was detected. The total phenol content shows good linear relation in both standard $\left(\mathrm{R}^{2}=0.950\right)$ as well as $\mathrm{MeOH}\left(\mathrm{R}^{2}=0.964\right)$ extract and $\mathrm{BuOH}\left(\mathrm{R}^{2}=0.966\right)$ extract. (Table 2, Figure 2)

\section{Reducing power}

Increase in absorbance of the reaction mixture indicated increased reducing power. The reducing power of the test extracts increases with the increased in amount of samples (Table 3). The reducing power shows good linear relation

Table $1 \%$ Inhibition of standard (ascorbic acid) and test drug

\begin{tabular}{lccc}
\hline $\begin{array}{l}\text { Concentra- } \\
\text { tion }(\boldsymbol{\mu} \mathbf{g} / \mathrm{ml})\end{array}$ & $\begin{array}{c}\text { \% Inhibition } \\
\text { MeOH }\end{array}$ & $\begin{array}{c}\text { \% Inhibition } \\
\text { BuOH }\end{array}$ & $\begin{array}{c}\text { \% Inhibition } \\
\text { STD }\end{array}$ \\
\hline 10 & 39.34 & 34.71 & 52.74 \\
15 & 43.41 & 39.74 & 62.33 \\
25 & 55.31 & 61.35 & 78.57 \\
50 & 79.46 & 72.17 & 98.79 \\
60 & 91.31 & 90.32 & 99.86 \\
\hline
\end{tabular}

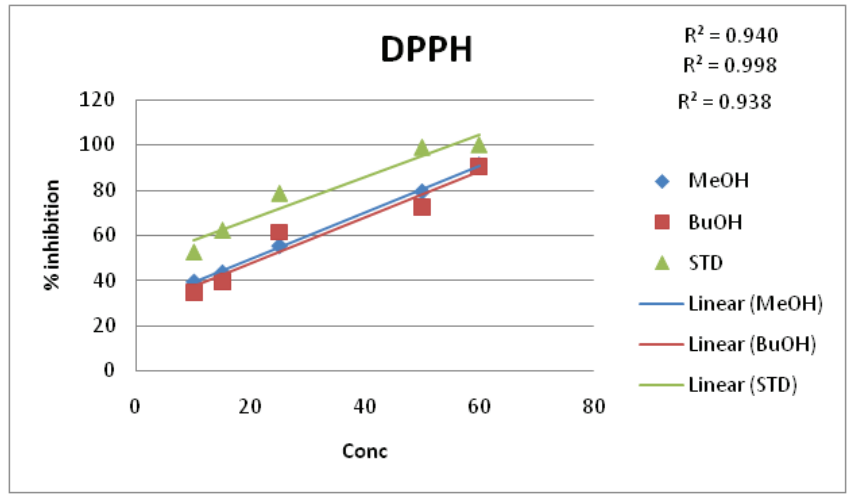

Figure 1. DPPH free radical scavenging activity- $\%$ inhibition versus concentration graph for standard and test drug. 
Pankaj B. Nariya, et al.: Phytochemical screening and in vitro evaluation of free radical scavenging activity

in standard $\left(\mathrm{R}^{2}=0.998\right)$ as well as $\mathrm{MeOH}\left(\mathrm{R}^{2}=0.994\right)$ extract and $\mathrm{BuOH}\left(\mathrm{R}^{2}=0.980\right)$ extract. (Figure 3)

Table 2 Absorbance at various concentrations $(\mu \mathrm{g} / \mathrm{ml})$ of standard (Gallic Acid) and test drug in total phenolic content

\begin{tabular}{cccc}
\hline $\begin{array}{c}\text { Concentra- } \\
\text { tion }(\mu \mathrm{g} / \mathrm{ml})\end{array}$ & $\begin{array}{c}\text { Absorbance - } \\
\text { MeOH }\end{array}$ & $\begin{array}{c}\text { Absorbance - } \\
\text { BuOH }\end{array}$ & $\begin{array}{c}\text { Absorbance - } \\
\text { STD }\end{array}$ \\
\hline 25 & 0.105 & 0.129 & 0.194 \\
50 & 0.323 & 0.293 & 0.395 \\
75 & 0.411 & 0.361 & 0.652 \\
100 & 0.525 & 0.531 & 0.790 \\
200 & 0.981 & 0.776 & 1.192 \\
250 & 0.1013 & 0.892 & \\
\hline
\end{tabular}

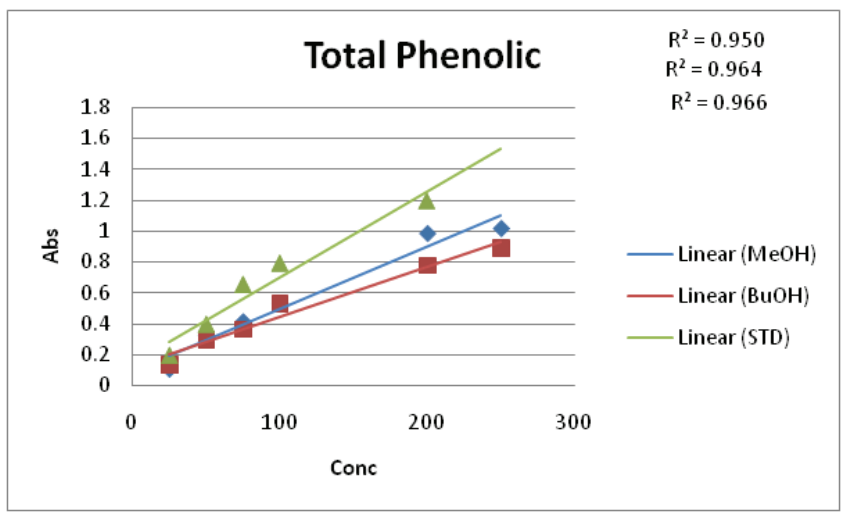

Figure 2. Effect of $\mathrm{MeOH}$ and $\mathrm{BuOH}$ extract of C. macleodii on $\mathrm{OH}$ radical scavenging activity. (Absorption versus Concentration)

Table 3 Absorbance of various concentrations $(\mu \mathrm{g} / \mathrm{ml})$ of standard (ascorbic Acid) and test drug in ferric reducing power

\begin{tabular}{cccc}
\hline $\begin{array}{c}\text { Concentra- } \\
\text { tion }(\boldsymbol{\mu g} / \mathrm{ml})\end{array}$ & $\begin{array}{c}\text { Absorbance - } \\
\text { MeOH }\end{array}$ & $\begin{array}{c}\text { Absorbance - } \\
\text { BuOH }\end{array}$ & $\begin{array}{c}\text { Absorbance - } \\
\text { STD }\end{array}$ \\
\hline 10 & 0.052 & 0.082 & 0.09 \\
25 & 0.121 & 0.097 & 0.122 \\
50 & 0.218 & 0.189 & 0.240 \\
75 & 0.291 & 0.276 & 0.352 \\
100 & 0.376 & 0.318 & 0.471 \\
\hline
\end{tabular}

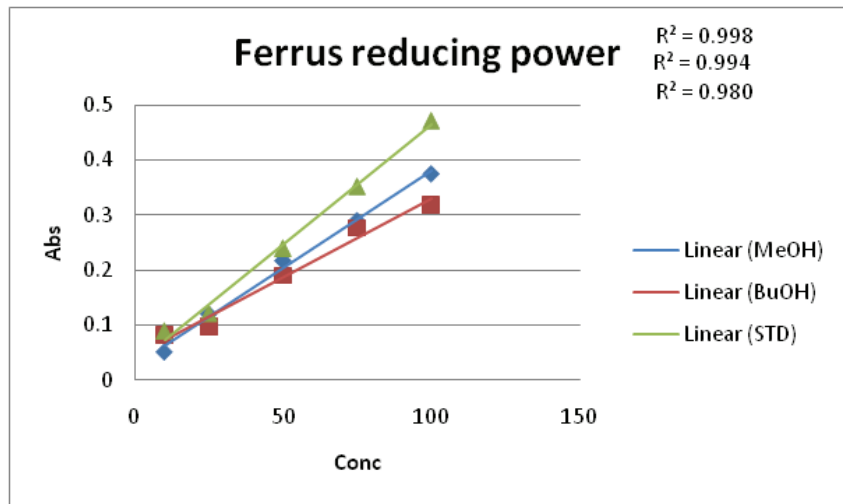

Figure 3. Effect of $\mathrm{MeOH}$ and $\mathrm{BuOH}$ extract of C. macleodii on reducing power assay. (Absorption versus Concentration)

\section{DISCUSSION}

Reactive oxygen species (ROS) are involved in the pathogenesis of various diseases. Uncontrolled oxidation is caused by free radicals. Natural antioxidants that are present in herbs and spices are responsible for inhibiting or preventing the deleterious consequences of oxidative stress. Spices and herbs contain free radical scavengers like polyphenols, Flavonoid and Phenolic compounds. The effect of antioxidants on DPPH radical scavenging is thought to be due to their hydrogen donating ability. The DPPH assay is technically simple, but some disadvantages limit its applications. Besides the mechanistic difference that normally occurs between antioxidants and peroxyl radicals, DPPH is long-lived nitrogen radical, which bears no similarity to the highly reactive and transient peroxyl radicals involved in lipid peroxidation. Many antioxidants that react quickly with peroxyl radicals may react slowly or may even be inert to DPPH. ${ }^{[21]}$

Phenolic compounds are known as powerful chain breaking antioxidants. Phenols are very important plant constituents because of their scavenging ability due to their hydroxyl groups. The Phenolic compounds may contribute directly to antioxidative action.

Ferric reducing antioxidant power (FRAP) measures the ability of antioxidants to reduce ferric 2, 4, 6- triperidyl-s-triazine complex to intensively blue colored ferrous complex in acidic medium. Hence any compound which is having redox potential lower than that of redox pair $\mathrm{Fe}$ (III)/Fe (II) can theoretically reduce $\mathrm{Fe}$ (III) to $\mathrm{Fe}$ (II). ${ }^{[21]}$

\section{CONCLUSION}

C. macleodii showed strong antioxidant activity by inhibiting $\mathrm{DPPH}$, and reducing power activities when compared with standard L-ascorbic acid. In addition, both extracts of bark was found to contain a noticeable amount of total phenols, which play major role in controlling oxidation. The results of this study show that the extracts of C. macleodii bark can be used as easily accessible source of natural antioxidant. However, the chemical constituents present in the extract, which are responsible for this activity, like flavonoid, alkaloids, steroids, terpenoids, tannins, reducing sugars and proteins present in the extract may be responsible for such activity. Some of these constituents have already been isolated from this plant. Hence, the observed antioxidant activity may be due to the presence of any of these constituents. 


\section{Pankaj B. Nariya, et al.: Phytochemical screening and in vitro evaluation of free radical scavenging activity}

\section{ACKNOWLEDGEMENTS}

We are grateful to Director, IPGT\&RA, Vice chancellor-GAU-Jamnagar for their encouragement and providing special permission to use the research facilities to undertake this programme.

\section{REFERENCES}

1. Shahidi F, Wanasundara PD. Phenolic antioxidants. Cri. Rev. Food Sci. Nutr. 1992; 32: 67-103.

2. Buyukokuroglu ME, Gulcin I, Oktay M, Kufrevioglu OI. In-vitro Antioxidant properties of dantrolene sodium. Pharmacol Res. 2001; 44: 491-4.

3. Finkel T, Holbrook NJ. Oxidant, oxidative stress and the biology of Ageing. Nature. 2000; 408: 239-47.

4. Farber JL. Mechanisms of cell injury by activated oxygen. Environmental Health Perspectives. 1994; 102: 17-24.

5. Park EJ, Pezzuto JM. Botanicals in cancer chemoprevention. Cancer and Metastasis Reviews. 2002; 21: 231-55.

6. Zi X, Mukhtar H, Agarwal R. Novel cancer chemopreventive effects of a flavonoid antioxidant silymarin: Inhibition of mRNA expression of an endogenous tumor promoter TNFa. Biochemical and Biophysical Research Communications. 1997; 239: 334-9.

7. Liu $\mathrm{F}, \mathrm{Ng}$ TB. Antioxidative and free radical scavenging activities of Selected medicinal herbs. Life Sciences. 2000; 66: 725-35.

8. Hu C, Kitts DD. Studies on the antioxidant activity of Echinacea root extract. Journal of Agricultural and Food Chemistry. 2000; 48: 1466-72.

9. Cadenas E, Packer L. (eds), Hand Book of Antioxidants, Plenum New York. 1996.
10. Aqil F, Ahmed I, Mehmood Z. Antioxidant and free radical scavenging properties of twelve traditionally used Indian medicinal plants. Turk J Biol. 2006; 30: 177-18.

11. Dubey PC, Sikarwar RLS, Tiwari A. Ethobotany of Cordia macleodii. Shodha samagya. 2008; 2(1-2): 31

12. Nariya PB, Bhalodia NR, Shukla VJ, Nariya MB. In vitro, Evaluation of antimicrobial and antifungal activity of $C$. macleodii bark. International Journal of PharmTech Research. 2010; 2: 2522-6.

13. Ibidem 1

14. Alan L, Miller ND. Antioxidant flavonoids: structure, function and Clinical usage. Alt. Med. Rev. 1996; 1, 103-11.

15. Anandjiwala S, Bagul MS, Parabia M, Rajani M. Free Radical Scavengingactivity of Panchvalkala, Indian Journal of Pharmaceutical Sciences. 2008 January - February: 31-5.

16. Ravishankar MN, Srivastava N, Padh H, Rajani M. Evaluation of antioxidant propertiesof root bark of Hemidesmus indicus, Phytomedicine. 2002; 9: 153-60.

17. Navarro CM, Montilla MP, Martin A, Jimenez J Utrilla MP. Free radical scavenging and antihepatyotoxic activity of Rosamarinus tomentosus, Planta Med. 1993; 59: 314

18. Bagul MS, Ravishankar MN, Padh H, Rajini M. Phytochemical evaluation and free radical scavenging activity of rhizome of Bergenia ciliate (Haw) Sternb: Forma ligulata Yeo, J Nat Rem. 2003; 3: 83-9.

19. Singleton VL, Rossi JA Jr. Colorimetry of total phenolics with phosphomolybdic Acid-phosphotungstic acid reagents. Am. J. Enol. Viticult. 1965; 16:144-58.

20. Oyaizu M. Studies on products of browning reactions: antioxidant activities of products of browning reaction prepared from glucose amine. Jap J Nutr. 1986; 44: 307-15.

21. Ghaisas MM, Navghare VV. In vitro antioxidant activity of Tectona grandis Linn Pharmacology online. 2008; 3: 296-305. 